Article

\title{
Confucian Exemplars and Catholic Saints as Models for Women in Nineteenth-Century Korea
}

\author{
Deberniere Torrey \\ Department of World Languages and Cultures, University of Utah, Salt Lake City, UT 84112, USA; \\ d.torrey@utah.edu
}

Received: 10 March 2020; Accepted: 18 March 2020; Published: 24 March 2020

\begin{abstract}
Women in Joseon Korea (1392-1910) were held to high standards of virtue, which were propagated through didactic texts such as the "Chaste and Obedient Biographies" volume of Lienü Zhuan, the Chinese classic featuring biographies of exemplary women. Joseon women who converted to Catholicism were also educated in standards of Catholic virtue, often through the biographies of saints, which shared with the Confucian exemplar stories an emphasis on faithfulness and self-sacrifice. Yet, the differences between Confucian and Catholic standards of virtue were great enough to elicit persecution of Catholics throughout the nineteenth century. Therefore conversion would have involved evaluating one set of standards against the other and determining that Catholicism was worth the price of social marginalization and persecution. Through a comparison of the Confucian exemplar stories and Catholic saints' stories, this paper explores how Catholic standards of virtue might have motivated conversion of Joseon women to Catholicism. This comparison highlights aspects of the saints' stories that offered lifestyle choices unavailable to women in traditional Joseon society and suggests that portrayals of the saints' confidence in the face of human and natural oppressors could also have provided inspiration to ease the price of conversion.
\end{abstract}

Keywords: early Korean Catholicism; Confucianism; women and Catholicism; Catholic saints

\section{Introduction}

In a letter written from prison during the persecution of Catholics in 1801, Ludgarda Yi Suni (1779-1802) mentions sending a note to her husband imprisoned elsewhere. The note read, "Let us die for the Lord together on the same day" (Yi 2014, p. 205). There was, in fact, little Ludgarda and her husband could do to ensure dying together. Their lives were under the control of the detaining authorities, and their Catholic faith forbade them from committing suicide. Yet, in her description of this incident, Ludgarda mentions the curious phrase, "die together on the same day", three times. The context shows that the phrase is an expression of the couple's intent to be martyred when they were arrested for being Catholic and ordered to recant their faith, and Ludgarda is reminding her husband of their intent so that he might be encouraged and strengthened to remain faithful in the face of torture and the threat of death.

In its phrasing and in its representation of a joint act of faithfulness, Ludgarda's phrase appears to be a variation on a phrase from a story in Lienü Zhuan, the Chinese classic that features the biographies of women who undertook great acts of self-sacrifice to preserve morality. The story is about the wife of the king of $\mathrm{Xi}$, taken by the invading king of Chu while her husband is forced to keep the city gate. She finds a moment to slip away to tell her husband that she will kill herself out of faithfulness to him rather than be wed to the king of Chu. Her husband tries to dissuade her, but she indeed kills herself, and he soon follows her in death by likewise committing suicide. Thus, they "die together on the same day" out of faithfulness to each other and to the principles of propriety that the Lienü Zhuan was published to promote (National Hangeul Museum 2015, pp. 87, 89). 
The Lienu Zhuan, or Yeolyeo Jeon, as it is titled in Korean, was translated into vernacular Korean and propagated in Korea during the Joseon period (1392-1910) to promote morality among Joseon women. Although Ludgarda Yi Suni was born into a Catholic home, as the daughter of an elite yangban family at a time when most Joseon Catholics followed whatever Confucian customs did not conflict with the Church's injunctions, she would have been educated in Confucian ideals alongside Catholic doctrine. Her letters from prison are quite unlike other Joseon women's writing from this period in their representation of Catholic ideals, but certain features, such as her expressions of filial piety, do reflect the Confucian side of her upbringing. ${ }^{1}$ Thus, it is quite likely that Ludgarda is referencing the phrase from Yeolyeo Jeon and using it as a trope for her and her husband's joint intent of martyrdom. At the same time, in her expressed desire for martyrdom, Ludgarda is voicing a sentiment repeated frequently in the stories of Western Catholic saints.

This detail from Ludgarda's letter reflects the co-influence of Confucian and Catholic ideals that is found in many of the earlier Korean Catholic sources. As is often the case in religious conversion, those who converted to Catholicism in the Joseon period were compelled by the way it both reinforced and supplemented their pre-existing values. This is reflected in their insistence, in the face of being branded by the Joseon state as rebels against tradition, that they were in fact upholding the traditional values of filial piety and loyalty by being faithful to God, the "great lord and great father" (Daegun Daebu n.d.). Yet, as the Joseon state's hundred years of persecution of Catholics attests, there were deep incompatibilities between Catholic and traditional Joseon modes of operation. ${ }^{2}$

Among the various criticisms of Catholicism by the Joseon state was that it allowed men and women to mix, which went against the Confucian rule of separation between the sexes, and that it allowed women to remain unmarried, which interfered with their primary role as wives and mothers (Cho 1988, p. 164; Jeong 2002, p. 248). As these criticisms suggest, Catholicism offered opportunities for Joseon women that were unavailable in a traditional context. Yet, Catholicism presented its own strict standards of behavior. Conversion would have involved, at some level, weighing one set of standards against the other, judging that Catholic standards of virtue were better and then, as required by conversion, adapting some and rejecting other pre-existing norms.

How might Confucian and Catholic models for women have informed this process of evaluating standards of virtue and choosing one over the other as one's primary point of reference? This question may be explored in part by comparing the models of behavior from the aforementioned Yeolyeo Jeon with the female saints featured in Seongnyeon Gwangik (holy year for widespread benefit), a Catholic text that featured a saint's biography for every day of the year. The narrative content of these two texts is comparable in that both present biographies of people who undertook heroic acts of self-sacrifice for the sake of moral and/or spiritual principles, and these biographies were propagated to educate and inspire others to act likewise. Yeolyeo Jeon stories were reprinted in other didactic texts for Joseon women, while some of the Catholic saints' stories appeared also in a Bible commentary that was central to the devotional lives of Joseon Catholics. Because Joseon Catholics had little direct clergy leadership until persecution ended in the 1880s, texts such as Seongnyeon Gwangik, read and relayed by lay Catholics individually, or communally in secret gathering places, were even more important as sources of guidance. Thus, the actions, the rewards, and the risks represented in these saints' stories would have affected the formation of Joseon Catholics, men and women alike. In the following pages, I will examine the virtues modeled by the female protagonists of these two texts and highlight comparative aspects of the saints' stories that would have motivated conversion and continued adherence to Catholicism.

\footnotetext{
For a discussion of Yi Suni's Confucian-Catholic hybridity, Cf. (Torrey 2015).

For more on the conflict between Confucianism and Catholicism in Joseon Korea, Cf. (Baker 2017, pp. 3-120).
} 


\section{Obedience and Chastity}

Thematically, the Confucian exemplar biographies propagated during Joseon and the Catholic female saints' biographies appear comparable in their emphasis on obedience and chastity. The original Yeolyeo Jeon was composed of several volumes, each emphasizing a particular virtue, and included stories of women who outdid their menfolk in bravery, skill, and wisdom. However, evidently "Chaste and Obedient Biographies" was the volume of Yeolyeo Jeon most widely promoted in the Joseon period, with the result that the "yeol" (列) of "yeolyeo", meaning "various", came to be understood as the “yeol" (烈) for "chaste and devoted" (Bak 2015, p. 209). Thus, during the Joseon period, the phrase "biographies of various women" became synonymous with "biographies of chaste and obedient women". As Moon Young-ho states, "The fact that [the "Chaste and Obedient Biographies"] volume has survived while the others have been lost is probably not a coincidence, likely being related to efforts to strengthen Confucian principles in the late Joseon society" (Moon 2015, p. 9). ${ }^{3}$ Moon's reference is to the Joseon-era expectations of women to uphold order in the family and in society through the separation of duties between men and women, by being faithful to one husband even after the husband's death, and by obeying moral principles regardless of one's own immediate needs. These values are represented in the Confucian exemplar stories by women, such as that of the widow of the king of $\mathrm{Wi}$, whose betrothed dies in battle as she is on her way to him. The king's successor then asks for her hand, but she refuses and remains the widow of her betrothed (National Hangeul Museum 2015, pp. 45-51). ${ }^{4}$ Baixi, another faithful widow, shows her adherence to moral principle by remaining trapped in a burning building rather than walking out unaccompanied because that would go against the behavior of a proper wife (National Hangeul Museum 2015, pp. 32-43).

The Catholic female saints in the biographies read by Joseon Catholics were also honored for their obedience and for their chastity. In the Catholic tradition, chastity was a category of virtue applicable to both men and women, and most of the male saints featured in the saints' biographies were celibate priests and bishops. However, in the case of the female saints, "virgin" was a category stated in the title of almost every biography. This was either in reference to nuns who were canonized for their outstanding piety, such as Catherine of Sienna or Clare, St. Francis' friend and follower, or to the "virgin martyred" who had decided to maintain their virginity for the Lord, and were killed by pagan persecutors, often the very men whose advances they had rejected. Susanna, one of the better-known examples, resolved, at age fifteen, to remain a virgin dedicated to the Lord, but was later killed by the king for spurning his son and for refusing to give up her religious vow (Jo 2014a, Chugye pp. 300-4). In the extant version of the saints' biographies read by Joseon Catholics, the few female biographies titled simply "martyred" feature young women who had not vowed to remain virgins, but were martyred while still unmarried, sometimes for refusing pagan suitors. ${ }^{5}$ Thus, the Catholic female biographies, similar to the Confucian exemplar stories, emphasized virginity alongside obedience.

However, it is at this superficial point of comparison - the parallel emphases on obedience and chastity-that the fundamental differences between what is represented by the Confucian exemplars and by the Catholic saints also emerge. The main characterization of these differences might be stated as a "this-worldly" versus "other-worldly" orientation. For the Confucian exemplars, although their obedience was primarily to transcendent ideals of propriety and only secondarily to human authority figures, these ideals were understood as undergirding the orderly maintenance of this-worldly human relations and social hierarchies, not soul salvation in heaven. As for the Catholic saints, although piety usually involved obedience to religious superiors, the human authority in those cases represented God,

3 Cf. (Gang 2015, pp. 231-32).

4 The entry for each story in the Yeolyeo Jeon edition referenced here includes the Chinese version of the story, the pre-modern Korean vernacular version, and a modern version, alongside illustrations. Hence, the page range for each of these references is quite long, although the stories themselves are short.

5 Cf. Prisca (Jo 2014b, Chungye pp. 206-7) and Theodora (Jo 2014d, Hagye pp. 751-54). 
the Catholic's primary reference point, and obedience was necessary for the salvation of the saint's individual soul, not simply for the proper maintenance of society.

Accordingly, the ideal of chastity in the saints' stories diverges from the Confucian exemplar stories in its social application, even to the extent of possibly undermining the Confucian emphasis on family continuity. In Joseon society, a woman's primary duty was to bear heirs to maintain her husband's family line. By remaining faithful to her husband even after his death, she would avoid disrupting the patrilineal kinship line by bearing the sons of another man. The implied link between chastity on the part of the wife and the proper continuation of the family line is poignantly illustrated by a detail in a woodblock print that accompanies the exemplar story of Gaoxing, a young widow whose beauty and virtue attract the attention of the king of Liang. To repel the king's advances and remain faithful to her late husband, Gaoxing cuts off her nose (National Hangeul Museum 2015, pp. 168-77). The woodblock illustration of this scene, in which Gaoxing holds a knife up to her nose, includes the figure of her young son clinging to her (National Hangeul Museum 2015, pp. 168-69). Nayeon Kim observes that the figure of the son further emphasizes Gaoxing's virtue by making "evident that she has already fulfilled her female virtue of maintaining the patriline" by giving birth to a son (Kim 2018, p. 75). I would add that the son's presence also emphasizes the importance of Gaoxing's chastity, because he represents the patrilineal link whose parentage and reputation must be protected.

Chastity within marriage to the spouse with whom one would bear children was expected of ordinary Catholics. However, in the biographies of the saints who were upheld as heroes of the faith, chastity was about remaining a virgin consecrated to the Lord. As such, it involved a refusal to procreate and thus undermined the importance placed on maintaining a family line. Practically, Catholic celibacy would likely have had little effect on the maintenance of family lines and proper population growth in the Joseon period, because, for every Catholic who chose celibacy, there were many more who chose to have families. Nevertheless, the practice was troubling to the Joseon authorities for at least two reasons. Rules of propriety were considered the backbone of order in the Joseon era, and divergence, even on a small scale, was seen as a threat to order. Secondly, in the strict Joseon hierarchy that placed each person within a clearly defined network of authority and accountability, a woman was under the authority of her father before marriage, her husband after marriage, and her son after the death of her husband. ${ }^{6}$ These male family members were, in turn, under the authority of their superiors and, ultimately, the king. When women chose to remain unmarried and childless and then outlived their fathers, they were stepping outside these clearly demarcated lines of authority. The Catholic model of chastity, by presenting non-marriage as a noble option, meant that a woman could be virtuous while avoiding the confines of the traditional female role, whereas the Joseon model of virtue emphasized the woman's subservience to her spousal and maternal roles. Unsurprisingly, many women among the first generation of Korean Catholics chose celibacy. ${ }^{7}$ The state responded by denouncing the Catholics' defiance of the moral duty of marriage and referenced, in their criticism, this trend among Catholic women to choose celibacy (Cho 1988, p. 153).

\section{The Place and Status of Women}

A related feature of Catholicism, which we see represented in the saints' biographies, was more interaction between men and women and representation of women alongside men and outside the domestic sphere. In contrast, the introduction to the Confucian exemplar stories references the importance of "strict adherence to the separation between man and wife" (National Hangeul Museum 2015, p. 21). This principle of separation was encapsulated in the passage from Mengzi stating that between husband and wife there must be "attention to their separate functions" and in the phrase from the Book of Rites stating that "[b]oys and girls from the age of seven do not sit together" (Mengzi Teng

6 This was called the Rule of Three Followings (三從之道삼종지도).

7 Cf. (Jeong 2002). 
Wen Gong I 5.4/29/10-11; Sturgeon 2011a, Nei Ze). ${ }^{8}$ Application of this principle included rules that restricted women to the home and limited their education to domestic and moral instruction specific to their roles as daughters, wives, and mothers. Interactions with men, including husbands, were strictly circumscribed, and rules of separation applied even to the domestic space, where husbands and wives occupied separate living areas. ${ }^{9}$

In the exemplar stories, this principle is emphasized by the story of Mengxi. Although most of the exemplar stories are about women remaining faithful to dead, ill, imprisoned, or abusive husbands, Mengxi is praised for guarding the principle of separation, even at the risk of death. When Mengxi is traveling with her husband, Duke Xiao of Qi, an accident causes her to fall from the palanquin that allowed her to travel in concealment, and the palanquin is ruined in the crash. Mengxi immediately has her servants shield her with a tent. Duke Xiao tells her to move to the standing carriage that he and the men are riding, but Mengxi, whose attention to propriety is unparalleled, insists that it would be better for her to remain by the side of the road and risk death than betray decorum by riding with the men and in plain sight (National Hangeul Museum 2015, pp. 69-83). In the closing line of the story, Mengxi is praised specifically for not riding in the wagon with her husband (National Hangeul Museum 2015, p. 83).

The women in the Catholic saints' stories were, of course, restricted by the paternalism of the ancient and medieval societies in which they lived, and their earthly status was never as high as that of the male priests and bishops. Moreover, stories about male saints far outnumber those about female saints. Nevertheless, the fact that they were represented alongside male saints and that their stories were read by men as well as by women signified a much lesser degree of exclusion. Furthermore, the most honored of the saints was a woman: Mary, the mother of Jesus. Granted, she was subservient to God the Father and to Jesus her son, but so was everyone else, men and women alike. In earthly matters, Catholic female saints often answered to men, and nuns were under the authority of male priests and bishops, but in the spiritual realm, all souls were equal before God, and this principle found expression also in cases of cooperation or association between male and female saints in some of the saints' stories.

Of particular interest is a detail from the biography of St. Scholastica, a nun and the sister of St. Benedict, a monk. One day when Scholastica is visiting her brother near his Abbey, knowing her death is imminent, she asks Benedict to stay with her for the evening. Benedict refuses, because it is against the rules to spend the night outside his monastery, rules that help the monks avoid, among other things, extended private interaction with women. Scholastica prays, and a sudden storm prevents Benedict from leaving. Benedict understands that the intervention is from God and stays with Scholastica the whole night (Jo 2014b, Chungye pp. 293-95). The fact that Scholastica and Benedict were siblings lessened the degree of their deviance from the rules, but it is nonetheless notable that God would intervene to grant Scholastica's request to facilitate this divergence from social propriety.

Another story of note featuring friendship between a woman and a man is that of St. Theodora and St. Didymus, featured together. Theodora is sent to a brothel because she resists the advances of pagan men and is helped by Didymus, a soldier, who gives her his clothes so that she can escape in disguise. Didymus is arrested and sentenced, at which time Theodora appears at the court to be martyred in his place. Didymus declares he also is prepared to die for the Lord, and the two are executed together (Jo 2014d, Hagye pp. 751-54). Each of the saints' stories in this Joseon-era Catholic text is followed by a passage instructing the reader on the "virtue to be rightly practiced", which the story has illustrated, and in this case, the virtue is "loving your friend". The passage instructs that when people help each other do good and, in that purpose, "love each other and become friends, Jesus'

8 References to the Mengzi cite page, section, and line numbers in the Harvard-Yenching Institute Sinological Index Series, No. 21, A Concordance to Mo Tzu, as quoted in Sturgeon (2011b). Locations of the textual references given in this paper can also be determined using the Chinese Text Project website: http://ctext.org/tools/concordance. 
love is most certainly between them" (Jo 2014d, Hagye p. 754). Thus, the commentary on the story of Theodora and Didymus specifically affirms this instance of friendship and cooperation between a man and a woman as an example of spiritual virtue.

In the practice of Catholicism in the Joseon period, this increased equalization was reflected in the fact that lay men and women received the same religious education and were held to the same standards of piety, whether these were ritual in expression, such as participating in the same religious sacraments, or behavioral, such as remaining faithful to one spouse, which was required of men as well as women. Whereas the Joseon model of strict separation between the sexes reinforced a woman's limitation to the domestic sphere and her subservient position, conversion to Catholicism enabled a woman to increase her sphere of influence, including in her saintly role as an example for both men and women to emulate. Hagiographic records from the early decades of Joseon Catholicism indeed feature many women as heroic role models. The first of these records, Hwang Sayeong's famous "Silk Letter", features many martyrs from the persecution of 1801, most of whom are men, but Hwang devotes more text to a description of the life and heroism of Columba Gang Wansuk than he does to most of the men he features (Hwang 2009, pp. 185, 197-200). In addition, a letter written by surviving Church leaders in 1811 features biographies of seven martyrs from 1801, three of whom are women, including the aforementioned Columba and Ludgarda (Francesco 2000, pp. 242-53). Furthermore, the biographies of these three women appear immediately after the opening biography of the martyred Fr. Zhou (a missionary from China) and before the remaining three biographies of lay male Catholics. The prominence of women is most notable, however, in a hagiography of martyrs from the persecution of 1839 , with a full 50 of the 78 featured martyrs being women (Gihae Ilgi n.d.).

The related theme of class impartiality in Catholic doctrine would have contributed to the appeal of the saints' stories specifically to women of the lower classes. The vernacular translation of Yeolyeo Jeon made it more accessible to commoner women, and the Joseon state's growing efforts to propagate Confucian morals among the lower classes suggested that such examples of morality were meant for commoners as well as the elite. However, the exemplars in the Yeolyeo Jeon stories are overwhelmingly from the elite classes. Ten of the fifteen featured exemplars include wives of kings and dukes and the wife of a military official. Even the five exemplars that are not identified as elite are nonetheless depicted as almost identical in dress and surroundings to most of the elite women in the accompanying illustrations. ${ }^{10}$ In contrast, only about half the women in the Catholic saints' stories are identified as social elites, and Mary the mother of Jesus, the most honored of the saints, is not one of them. Furthermore, the saints who come from elite families lose their privileges, either from anti-Christian persecution or by embracing poverty to become nuns. Thus, the themes of spiritual equality before God and the affirmation of poverty and suffering, themes that appear to have drawn many members of the Joseon lower classes to Catholicism in the first place, were reiterated in the saints' stories. ${ }^{11}$

\section{Worth the Price of Conversion}

What I have described thus far in comparing the Confucian exemplar stories with the Catholic saints' stories reiterates my earlier mention of Catholicism offering opportunities for Joseon women that were unavailable in a traditional context. There were, however, prices to conversion. Most apparent in this regard was the persecution that haunted Catholics for almost a century. For various reasons, some of which I have alluded to, the practice of Catholicism was outlawed in the Joseon period soon after its beginning in the 1780s, and Catholics were ruthlessly persecuted until a treaty with France in 1886 compelled the state to allow religious freedom. This persecution involved arrest and severe torture; imprisonment under harsh conditions, sometimes for years at a time; exile; and execution for most of those who refused to recant their Catholic faith. Joseon-era laws dictated that even the young

10 Cf. (National Hangeul Museum 2015, pp. 24-25, 52-53, 144-45, 180-81 ).

11 For discussions of Catholic doctrine and class issues in Joseon, Cf. (Bang 2006, pp. 186-90; Cho 1988, p. 128; Yi 2004, p. 175). 
children and other relatives of a Catholic could be penalized with exile and/or servitude. The first large-scale persecution of 1801 resulted in about 100 executions and 400 exile orders and eliminated most of the leadership. Smaller-scale persecutions during succeeding decades resulted in hundreds of arrests and about fifty deaths. The second large-scale persecution, which took place in 1839 and led to the first official Korean hagiography mentioned above, resulted in over a hundred deaths. The last and most brutal persecution, which began in 1866 and continued for seven years, resulted in the deaths of more than 8000 Catholics. Aside from the suffering of actual arrest and punishment, being Catholic in Joseon involved displacement, poverty, and other forms of marginalization.

Another price of being Catholic was the burden of being held to standards of behavior that had eternal consequences. A Joseon woman who failed to uphold propriety would bring disgrace to herself and her family, but there was nothing in the Confucian didactic literature that indicated that her action would lead to unending suffering in hell. Popular Joseon beliefs about the afterlife offered some notion of reward or punishment after death, but there was nothing comparable to the clearly articulated and extensive teaching about heaven and hell given in Joseon-era Catholic texts. In particular, the aforementioned Bible commentary that was integral to the devotional lives of Joseon Catholics emphasized the difficulty of attaining heaven and advised its readers to be constantly vigilant to avoid the horrors of hell. ${ }^{12}$

Despite this price in terms of both earthly suffering and the burden of spiritual vigilance to avoid eternal suffering, Catholicism continued to attract converts. Even with the losses of 1801 and 1839, including members leaving the church from fear of persecution, membership recovered to around 10,000 by the middle of the nineteenth century and grew to 23,000 by the start of the persecution of 1866 (Kim and Chung 1964, p. 231). This was, of course, a small minority of the Joseon population-most people were not compelled to convert. However, for those who did, the price was apparently worth what they gained from conversion.

The Confucian exemplar stories that I have introduced here represent a broader culture of moral education that primed Joseon women to be virtuous and self-sacrificial. For those women who converted to Catholicism, this pre-existing expectation of virtue and self-sacrifice made the expectations of Catholic virtue less difficult to fulfill than if they were converting from more liberal and self-indulgent modes of behavior. Moreover, as we have seen, Catholic standards of virtue offered a level of individual agency and status that were unavailable for women in the traditional context.

\section{Confidence in the Face of Suffering and Oppression}

The positive offerings of the saints' stories discussed here relate to aspects of Catholic doctrine and practice that have been discussed in other scholarship on the attractiveness of Catholicism to Joseon women. ${ }^{13}$ However, several characteristics particular to the saints' biographies and less a general feature of the Catholic doctrine encountered in nineteenth-century Korea also merit our attention as factors that likely contributed to the appeal of these stories.

One of these is what might be identified as a certain defiant boldness on the part of the saints. Alongside qualities such as perseverance and self-sacrifice, qualities that were expected of any Joseon woman, Confucian or Catholic, many of the female Catholic martyrs featured in the saints' biographies exhibit an unusual defiance when opposed or threatened by human authority figures. For their part, the women of the Confucian exemplar stories are also ready to chide their less virtuous superiors, such as parents and husbands, about the importance of propriety and virtue. As in the case of Mengxi telling her husband that she must follow propriety rather than get in the carriage with him, the exemplars are always featured stating their moral position, either in speech or in writing. However, this was expected of them by their social milieu: a good Confucian woman should help others to act

12 For a more detailed discussion of this text and its emphasis on judgment, Cf. (Torrey 2020).

13 Cf. (Kim 2003a, 2003b, 2008; Jeong 2002, 2005). 
virtuously, through exhortation as well as guidance and example. Thus, even when contradicting their superiors, the exemplars were upholding the Confucian moral status quo. Furthermore, such actions were frequently rewarded by a change of heart on the part of the person in authority, absolving the exemplar's contradictory stance. For instance, when Gaoxing repels the king's advances by cutting off her nose, the king is moved by her sacrifice and grants her a special status (National Hangeul Museum 2015, pp. 168-69). Similarly, when the wife of the late king of Chu holds a knife to herself and reprimands the invading king of Wu for trying to rape her, he is ashamed, and leaves her in peace (National Hangeul Museum 2015, pp. 128-29). In contrast, many of the Catholic martyr stories feature young women who boldly defy male authority figures to the extent of incurring their increasing wrath. This would usually result in increasingly severe torments for the martyrs, who would bear it all with superhuman courage. ${ }^{14}$ One of the most striking examples is that of thirteen-year-old Eulalia, who boldly rebukes Diocletian, the emperor, when he seeks to persecute Christians. She declares that despite her age, God gives her courage, and she is unafraid of suffering, which she proves by remaining firm under torture (Jo 2014c, Donggye pp. 952-54).

As in the above story, the majority of the saints' stories describe their protagonists undergoing severe physical suffering at some point, from either disease or torture, but in the end, these sufferings become inconsequential. In the case of Eulalia, even as she is being burned, she declares-her voice ringing clearly through the flames-that she will be rewarded and her tormentors will be punished by eternal fire (Jo 2014c, Donggye p. 953). Elsewhere in the saints' biographies, women who are wracked by physical ailments embrace their bodily sufferings and die in peace, thus psychologically defying these oppressors of nature. ${ }^{15}$

Such narrative features would have held special appeal to the Catholic demographic of nineteenth-century Joseon. Although Catholicism was first embraced and propagated in Joseon by a group of elite yangban scholars, by the turn of the nineteenth century, the majority of Joseon Catholics were members of the lower classes, who regularly faced oppression by human authorities and by the forces of nature. In particular, a confluence of political and natural factors made the decades of the nineteenth century particularly oppressive. The accession of a very young king in 1800 and the lack of heirs to succeeding kings, which necessitated adoptions into the king's line, made the court vulnerable to the manipulations of royal relatives. The corruption that attended these manipulations led to increased taxes and the expansion of landholdings among the royalty, thus increasing the hardships of the lower classes (Eckert et al. 1990, p. 179). Natural disasters and epidemics added to the woes of this period, with the cholera epidemic of the 1820s leaving in its wake not only death, but deep fears that led to exaggerated accounts of mortalities and to the transmission of traumatic memories to later generations (Kim 2016). ${ }^{16}$ Even the minority of Catholics from the yangban class were vulnerable to social oppression due to their association with a marginalized political faction, not to mention that the criminalization of Catholicism that went into full force with the persecution of 1801 affected the yangban as much as the commoners. ${ }^{17}$ To Joseon Catholic women of the nineteenth century, well acquainted with oppression, suffering, and persecution from their immediate environment, examples of women who defied their human persecutors and who faced fleshly oppressions with courage would have offered more relevance than examples of mostly elite women whose actions as moral exemplars reinforced their connection with mainstream social norms.

Another important feature of the saints' stories is the fantastical element. In a majority of the martyr stories, a saint's faithfulness in the face of persecution is rewarded or accompanied by

14 E.g., Agatha, Dorothea, Domitilla, Julia, Susanna, Serafina, Regina, Caterina, Bibiana, Lucia (Jo 2014b, Chungye pp. 276-79, 280-83; 2014d, Hagye pp. 821-25, 861-63; 2014a, Chugye pp. 300-4, 408-11, 422-25; 2014c, Donggye pp. 877-81, 916-17, 960-64).

15 E.g., Lidwina, Mary Magdalen of Pazzi, Etheldreda, Clara, and Theresa. Cf. (Jo 2014d, Hagye pp. 716-20, 880-87, 1012-14; 2014a, Chugye pp. 305-10; 2014c, Donggye pp. 700-5).

16 Fear of cholera even motivated some of the conversions to Catholicism. Cf. (Kim 2016).

17 For factionalism and Anti-Catholicism Cf. ( Baker 2017, 51, p. 96 ). 
miraculous intervention. Although this intervention lessens the saint's sufferings somewhat until she is eventually executed, it appears that the more significant effect of the interventions is to demonstrate God's power over the persecutors, because many saints suffer terribly despite the interventions. In the case of the nuns who are not martyred but are sainted for their piety, they are also rewarded by signs and miracles of healing that usually continue after their deaths, benefiting those who visit their tombs. For instance, St. Genevieve's mother is struck blind when she opposes her daughter, and miracles of healing and other signs, "too many to record", continue after Genevieve's death (Jo 2014b, Chungye pp. 154-56). St. Prisca is beaten and imprisoned, but when she is thrown to the lions, they leave her alone, and when thrown into the fire, she is unhurt (Jo 2014b, Chungye pp. 206-7). St. Martina's trials are interrupted by earthquakes, angels, a great fire that destroys a pagan shrine, and wind and rain that extinguish the fire into which she is thrown (Jo 2014b, Chungye pp. 247-50). Some saints, such as Caterina and Lidwina, are visited by Jesus and Mary (Jo 2014b, Chungye p. 403; 2014d, Hagye p. 720). Moreover, many of the featured nuns are given foreknowledge of their time of death. ${ }^{18}$ Thus, not only are these women more righteous and courageous than their oppressors, but their alliance with an omnipotent God frequently allows them super-hero-like qualities that further emphasize their superiority to human and natural oppressors. In contrast, the Confucian exemplar stories are much more down-to-earth, featuring no miraculous intervention. Realistic stories might be more believable, but in the face of suffering, fantastical stories could be more potent, especially when the featured miracles were supported by the weight of religious teaching and, as discussed earlier, the protagonists enjoyed a heightened agency even apart from any miracles.

\section{Conclusions}

As the preceding analysis has shown, for those Joseon women concerned with virtue and drawn to the claims of Catholicism, the stories of female Catholic saints suggested compelling possibilities unavailable to the Confucian exemplars, such as celibacy and less restricted interaction with and representation alongside men. Furthermore, the female saints embodied a level of defiance toward the status quo not found in the "Obedient and Chaste" Confucian exemplar stories. The saints might be obedient to God, but to tyrants, to bodily suffering, and to the devil, they thumbed their noses. Certainly, the real-world experiences of persecution on the part of Joseon converts would have corrected any unrealistic expectations fueled by such stories. They would have quickly discovered that persecution was horrible and traumatic, that heroism was difficult, and that miraculous interventions were rare or nonexistent. Nevertheless, fantasies of standing bold and victorious in the face of oppression and pain could inspire and thus render the price of conversion less burdensome.

Funding: This research was funded by the University of Utah College of Humanities International Travel and Research grant, and the University of Utah Asia Center Travel and Research grant.

Conflicts of Interest: The author declares no conflict of interest.

\section{References}

Bak, Cheolsang. 2015. Joseonbon Yeolyeo Jeon ui Seojijeok Euimi [the Bibliographic Significance of the Joseon Version of the Yeolyeo Jeon]. In Yeolyeo Jeon: Yeoreo Yeoseongdeul ui Iyagi [The Stories of Many Women]. Seoul: National Hangeul Museum, pp. 198-214.

Baker, Don. 2017. With Franklin Rausch. In Catholics and Anti-Catholicism in Chosŏn Korea. Honolulu: University of Hawai'i Press.

Bang, Sanggeun. 2006. 19 Segi Jungban Han'guk Cheonjugyosa Yeon'gu [Mid-19th Century Korean Catholic History Research]. Seoul: Han'guk Gyohoesa Yeon'guso.

18 E.g., Colette, Caterina, Euphrasia, Lidwina, Martha, and Clara. Cf. (Jo 2014b, Chungye pp. 377, 404, 415; 2014d, Hagye p. 720; 2014a, Chugye, pp. 249, 310). 
Cho, Kwang. 1988. Jjoseon Hugi Cheonjugyosa Yeon'gu [A study of Catholicism in Late Joseon]. Seoul: Koryo University Research Institute of Korean Studies.

Daegun, Daebu. n.d. Good News Catholic Dictionary. Catholic Church Seoul Diocese. Available online: http://dictionary.catholic.or.kr/dictionary.asp?name1=\%B4\%EB $\% \mathrm{~B} 1 \% \mathrm{BA} \% \mathrm{~B} 4 \% \mathrm{~EB} \% \mathrm{BA} \% \mathrm{CE}$ (accessed on 7 March 2020).

Eckert, Carter J., Ki-baik Lee, Young Ick Lew, Michael Robinson, and Edward W. Wagner. 1990. Korea Old and New: A History. Seoul: Ilchokak.

Francesco. 2000. Dong Guk Gyo'u sang Seo u Jugyo Seo [Letter to the Bishop from the Faithful of the Eastern Kingdom]. In Yun Yuil Baoro wa Dongnyo Sungyojaeul ui Sibok Jaryojip [A compilation of references for the beatification of Yun Yuil Paul and his fellow martyrs]. Suwon: Suwon Diocesan Community for the Promotion of Beatification, pp. 242-53.

Gang, Myeonggwan. 2015. Yuhang eui Go Yeolyeo Jeon gwa Samgang Haengsildo 'Yeolyeo Pyeon' [Yuhang's Go Yeolyeo Jeon and 'Yeolyeo Pyeon' as Featured in Samgang Haengsildo]. In Yeolyeo Jeon: Yeoreo Yeoseongdeul ui Iyagi [The Stories of Many Women]. Seoul: National Hangeul Museum, pp. 215-32.

Gihae, Ilgi. n.d. Good News Catholic Dictionary. Catholic Church Seoul Diocese. Available online: http: //maria.catholic.or.kr/dictionary/term/term_view.asp?ctxtIdNum=477\&keyword=\&gubun=01 (accessed on 7 March 2020).

Hwang, Sayeong. 2009. Baekseo [Silk letter]. In Hwang Sayeong Baekseo Yeon'gu: Wonbon gwa Ibon Bigyo Geomto [Hwang Sayeong's Silk Letter: A Comparative Examination]. Edited by Yeo Jincheon. Seoul: Han'guk Gyohoesa Yeon'guso, pp. 180-210.

Jeong, Hae-eun. 2002. Bongeon Cheje ui Dongyo wa Yeonseong eui Seongjang [The Disturbance of Feudalistic Structures and the Development of Women]. In Uri Yeoseong eui Yeoksa. Seoul: Cheongnyeonsa, pp. 225-50.

Jeong, Gilja. 2005. Gyubang Gasa eui Sajeok Jeon'gae wa Yeoseong Euisik eui Byeonmo [The Historical Development of Gyubang Gasa and the Change in Women's Consciousness]. Paju: Korean Studies Information.

Jo, Gyuman, ed. 2014a. Chugye. In Seongnyeon Gwangik [Holy Year for Widespread Benefit]. Seoul: Han'guk Gyohoesa Yeon'guso.

Jo, Gyuman, ed. 2014b. Chungye. In Seongnyeon Gwangik [Holy Year for Widespread Benefit]. Seoul: Han'guk Gyohoesa Yeon'guso.

Jo, Gyuman, ed. 2014c. Donggye. In Seongnyeon Gwangik [Holy Year for Widespread Benefit]. Seoul: Han'guk Gyohoesa Yeon'guso.

Jo, Gyuman, ed. 2014d. Hagye. In Seongnyeon Gwangik [Holy Year for Widespread Benefit]. Seoul: Han'guk Gyohoesa Yeon'guso.

Kim, Yongsuk. 1990. Han'guk Yeosoksa [a History of Korean Women]. Seoul: Mineumsa.

Kim, Jeongsuk. 2003a. Joseon Hugi Seohak Suyong gwa Yeoseong Gwan eui Byeonhwa [The Reception of Western Learning and the Changing View of Women in Late Joseon]. Han'guk Sasang Sahak 20: 35-82.

Kim, Yunseong. 2003b. Joseon Hugi Cheonnjugyo Seong'in Gonggyeong e Natanan Mom eui Yeongseong [The Spirituality of the Body in the Veneration of the Saints in Late Joseon Catholicism]. Ph.D. dissertation, Seoul National University, Seoul, Korea.

Kim, Jeongsuk. 2008. Cheonjugyo wa Yeoseong eui Mannam (1784-1831) [The Meeting between Catholicism and Women (1784-1831). In Yeoseong, Cheonjugyo wa Mannada. Edited by Kim Jeongsuk, Bak Ju, Son Sukgyeong, Sin Yeongsuk and Geum Gyeongsuk. Seoul: Han'guk Gyohoesa Yeon'guso.

Kim, Sinhoe. 2016. Yeokbyeong gwa Jaehae: 19 Segi Kollera Chungyeok gwa Joseon Sahoe eui Ban'eung [Epidemic and Disaster: the Shock of Cholera in the 19th Century and the Response of Joseon Society]. Korean History Society. September 6. Available online: http://www.koreanhistory.org/5060?ckattempt (accessed on 7 March 2020).

Kim, Nayeon. 2018. Indoctrinating Female Virtue: The Social Use of Chosŏn Woodblock Prints. In Gender, Continuity and the Shaping of Modernity in the Arts of East Asia, 16th-20th Centures. Edited by Kristen L. Chiem and Lara C. Blanchard. Leiden: Brill, pp. 53-78.

Kim, Joseph Chung-mun, and John Jae-sun Chung, eds. 1964. Catholic Korea: Yesterday and Today. Seoul: Catholic Publishing Company.

Moon, Young-ho. 2015. Foreword. In Yeolyeo Jeon: Yeoreo Yeoseongdeul ui Iyagi [The Stories of Many Women]. Seoul: National Hangeul Museum, pp. 8-9. 
National Hangeul Museum. 2015. Yeolyeo Jeon: Yeoreo Yeoseongdeul ui Iyagi [The Stories of Many Women]. Seoul: National Hangeul Museum.

Sturgeon, Donald, ed. 2011a. NeiZe. In Book of Rites. Chinese Text Project. Available online: https://ctext.org/liji/ nei-ze (accessed on 7 March 2020).

Sturgeon, Donald, ed. 2011b. Teng Wen Gong I. In Mengzi. Chinese Text Project. Available online: https: //ctext.org/mengzi/teng-wen-gong-i (accessed on 7 March 2020).

Torrey, Deberniere. 2015. Transcendence and Anxiety in the Prison Letters of Catholic Martyr Yi Suni Ludgarda (1779-1802). Religion and Literature 47: 25-55.

Torrey, Deberniere. 2020. Hard Road to Heaven: Soul Judgment in Korea's First Bible Commentary. Journal of Korean Studies 25.1: 35-55. [CrossRef]

Yi, Wonsun. 2004. Han'guk Cheonju Gyohoesa Yeon'gu [Korean Catholic History Research]. Seoul: Han'guk Gyohoesa Yeon'guso.

Yi, Suni. 2014. Du Eonni ege Bonaen Pyeonji [Letter to Two Sisters]. In Jugeum eul Neomeoseo: Sungyoja Yi Suni ui Okjung Pyeonji. Edited by Jung Byung-Sul. Seoul: Minumsa, pp. 203-14.

(C) 2020 by the author. Licensee MDPI, Basel, Switzerland. This article is an open access article distributed under the terms and conditions of the Creative Commons Attribution (CC BY) license (http://creativecommons.org/licenses/by/4.0/). 